\title{
WRITTEN CORRECTIVE FEEDBACK IN ACADEMIC WRITING CLASS: HOW DOES EXPERIENCED TEACHER LEAD THE EFFECTIVE PRACTICE?
}

\author{
Dayat \\ Language Education, Yogyakarta State University \\ Jalan Colombo Nomor 1, Karang Malang, Caturtunggal, Sleman, Yogyakarta \\ e-mail: 8117000004.2017@ student.uny.ac.id
}

\begin{tabular}{|c|c|c|c|c|c|}
\hline $\begin{array}{c}\text { Submitted } \\
2021-01-04\end{array}$ & $\begin{array}{c}\text { Accepted } \\
2021-05-19\end{array}$ & $\begin{array}{l}\text { Published } \\
2021-05-22\end{array}$ & open $\partial_{\text {Access }}$ & (c) (i) (8) & a sinta 3 \\
\hline
\end{tabular}

\begin{abstract}
The research aimed to investigate an Indonesian academic writing teacher's practice on written corrective feedback (WCF) in academic writing class. A case study involving an experienced Indonesian academic writing teacher and teacher students were employed. To gather data, a semi-structured interview was conducted. The data were then analyzed using the content analysis method. The findings indicated that the teacher's practice on WCF was mediated by her language learning experience. Thus, the teacher provided WCF on her students' writing drafts by considering the students' personalities and their level of writing ability. In correcting student writing errors, the teacher used several types of WCF; direct and indirect correction; metalinguistic clues to the errors; and the reformulation of the wrong words. The relevant pedagogical implications for teachers in conceptualizing WCF and in learning and practicing it on their daily instruction based on their knowledge, experience, and reflection-on-practice.
\end{abstract}

Keywords: writing teacher; academic writing; written corrective feedback.

\begin{abstract}
Abstrak
Penelitian bertujuan untuk mendeskripsikan praktik dosen Indonesia dalam penulisan akademik tentang umpan balik korektif tertulis (WCF) di kelas penulisan akademik. Penelitian termasuk studi kasus yang melibatkan seorang dosen Indonesia dalam menulis akademik yang berpengalaman dan mahasiswa. Untuk mengumpulkan data, dilakukan wawancara semi-terstruktur. Data tersebut kemudian dianalisis dengan menggunakan metode analisis isi. Temuan menunjukkan bahwa praktik dosen pada WCF dimediasi oleh pengalaman belajar bahasanya. Dosen memberikan WCF pada draf tulisan mahasiswanya dengan mempertimbangkan kepribadian mahasiswa dan tingkat kemampuan menulisnya. Dalam mengoreksi kesalahan menulis mahasiswa, dosen menggunakan beberapa jenis WCF; koreksi langsung dan tidak langsung; petunjuk kesalahan metalinguistik; dan perumusan ulang kata yang salah. Implikasi pedagogis yang relevan bagi dosen dalam membuat konsep WCF dan dalam mempelajari serta mempraktikkannya pada instruksi harian berdasarkan pada pengetahuan, pengalaman, dan refleksi pada praktik yang dilaksanakan.
\end{abstract}

Kata Kunci: dosen menulis; menulis akademik; umpan balik koreksi tertulis. 
Edukasi: Jurnal Pendidikan, Volume 19 Nomor 1 Tahun 2021

Written Corrective Feedback in Academic Writing Class.......

Dayat

Halaman 150-160

\section{INTRODUCTION}

In an English as a Foreign Language (EFL) writing context, written corrective feedback (WCF) in higher education (HE) is provided to assess and improve students' writing both disciplinary knowledge and writing aspects: the linguistics, the rhetoric, and the convention (Jabulani, 2017). In recent years, studies on WCF have proved its efficacy in improving student-written texts (Fhaeizdhyall \& Jerome, 2020; Jabulani, 2017; Putra \& Sulaiman, 2016; Yu \& Lee, 2016; Ferris, 2015; Lee, 2014). Providing WCF is one of the teachers' responsibilities to promote student writing development.

The majority of WCF studies examine the effectiveness of the different types of WCF, for instances, recast and direct correction in English as a foreign language (EFL) writing classes (Sabarun, 2020; Yunus, 2020; Banaruee et al., 2018; Susanti, 2017; Chen et al., 2016; Zabihi, 2013); direct and indirect correction in Spanish writing classroom (Thomas, 2018; Elola et al., 2017; Westmacott, 2017; Yang, 2017); the benefits of indirect correction in the Korean language as L2 (Park et al., 2015); student engagement with teacher WCF in EFL writing (Wei \& Cao, 2020; Zheng \& Yu, 2018); learner uptake and teacher perception on WCF in Chinese Language classroom (Fu \& Nassaji, 2016); and WCF in the German language classroom (Vyatkina, 2010). Very few have investigated WCF on the teacher education program. To fill this gap, the recent study explored the experienced teacher in providing WCF in order to improve written linguistic accuracy and text revision of English teacher students in Asian societies, particularly in Indonesia.

This research reports the result of a single-case study of an experienced Indonesian university teacher of EFL on how her experience channeled her practice of WCF. With more experience teachers, the value of feedback is 'boarder and more complex understanding' (Kunzman, 2003). However, this preliminary study aims to identify the teacher's provision of WCF practice. Although it is recognized that the studies on teacher's WCF from a general viewpoint are unfair for complex error correction processes, it is still a good starting point to eventually achieve a more complex, multidimensional insight of 
the WCF process. However, it is expected that this contextualized case study will provide beneficial insights for pre-service or novice English teachers in providing WCF practices in the Indonesian EFL context.

\section{METHOD}

A single-case design was undertaken by negotiating 15 participants of a 10year-experienced writing teacher in Indonesian universities, but only one who had been disposed to cooperate during the research. More importantly, the way Mrs. Sutiyem (pseudonym) provided feedback was the uniqueness of why she was selected. Therefore, her knowledge and experiences in teaching Academic Writing are useful to depict the implementation of corrective feedback in the Indonesia EFL context. At the time of the data collection, she was teaching an Academic Writing course to third-year students of English teacher education. She had large four academic classes, each of which consisted of 40 students.

The data gathered from a semi-structured interview were audio-recorded and transcribed. Also, classroom observation was carried out. The data were then analyzed using the content analysis method. The selected unit analyses of the interview data were manually coded by referring to the research question: How does the experienced teacher effectively provide WCF to Indonesian EFL students? To strengthen the findings of this single case study, participant observation of the writing classroom and interviews with two students of each class were also carried out to triangulate the data from Mrs. Sutiyem. Eight students brought their corrected writing works while being interviewed to identify the teacher's WCF practices.

\section{FINDINGS AND DISCUSSION}

The findings of this present case study address themes on teacher experience on WCF practices including the benefits of WCF, particularly, students' motivation and personality in learning academic writing and teacher's practices on WCF embraced the types of WCF, language elements, and WCF provision. In respect o relating the teacher, Mrs. Sutiyem's provision of WCF on the written 
Edukasi: Jurnal Pendidikan, Volume 19 Nomor 1 Tahun 2021

Written Corrective Feedback in Academic Writing Class.......

Dayat

Halaman 150-160

text was identified from the interview data and students' writing artifacts. Mrs. Sutiyem's practice on WCF was mediated by her language learning experience when she confirmed that writing was a complicated activity for most Indonesian EFL students. Therefore, she expected that her provision of WCF on her students' writing drafts helped them boost their language accuracy and be more accurate in their writing as in excerpt 1.

\section{Excerpt 1}

"I think providing WCF helps students to improve their accuracy and to be more careful in writing since they know the errors they have made." (Teacher interview, January 8).

Furthermore, Mrs. Sutiyem's intention to improve the level of the students' motivation was based on her experience of whether or not the students could be motivated to refine their writing by referring to the WCF she had provided. It is in line that effective WCF is when students are engaged to respond to the teacher's WCF (Ellis, 2010 \& Ferris, 2011). When WCF gave, Mrs. Sutiyem's WCF provision depended on the students' personality and their level of writing ability. She believed when appropriate ways of WCF were conducted, the students would be able to better understand the errors they made and what they revised. To avoid embarrassing her students and creating an untoward learning environment, Mrs. Sutiyem's returned the students' writing drafts personally after one week or the next meeting as stated in Excerpt 2 by e-mail.

Excerpt 2

"To be more thorough, the next meeting I gave back their draft, the correction I did adjust the level of ability of students, obviously each individual was different so the correction given was also different. Then, the corrected drafts were shared individually so that they were not ashamed of the results they got, as a result, it also kept them motivated in learning." (Teacher interview, January 8).

Related to the WCF practices, although such practices are claimed as time and energy-consuming, Mrs. Sutiyem was enthusiastic about correcting her students' writing works. She argued that she had to do so since her WCF could help her students to improve writing quality. 


\section{Excerpt 3}

“Indeed, correcting students' draft was exhausting but I had to do since it was my duty to help my students improve their writing ability. From the correction I had given, they could improve their writing quality by revising they are the draft." (Teacher interview, January 8).

The types, the elements, and the social function regarding Mrs. Sutiyem's WCF on her student writing were mostly found in the interview. In providing WCF, Mrs. Sutiyem used various types, including directly delivering forms on student errors (direct correction feedback); indicating and locating (eg. circling) an error without correction (indirect correction); giving metalinguistic clues to the errors (eg. the word 'past', indicates mistakes on the use of simple past tense); and reformulating the wrong words (eg. interesting instead of interested) (for further details, see the students' worksheets in Figure 1 till 4).

Providing WCF using direct technique facilitated the students in understanding their writing errors. The teacher said that she used this type by underlining/circling and gave the alternatives of the incorrect form. In fact, this technique had low frequency on WCF provision, whereas it was the most favorable type of correction for the students as they felt that it was useful to know immediately the correct forms. Figure 1 provides the way the teacher gave direction correction to students' writing.

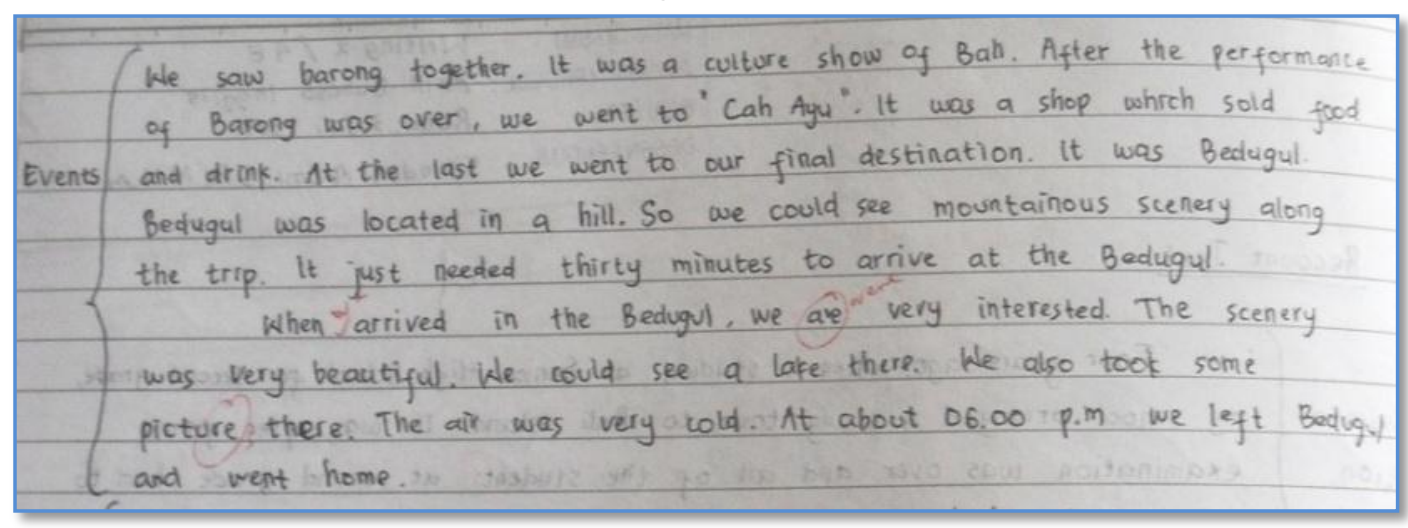

Figure 1 Direct WCF

In the interview, indirect WCF was also provided. This type was more frequently used than others. The strategy of using this correction was indicating 
Edukasi: Jurnal Pendidikan, Volume 19 Nomor 1 Tahun 2021

Written Corrective Feedback in Academic Writing Class.......

Dayat

Halaman 150-160

errors by circling. The teacher thought that the students enabled to solve the writing problems.

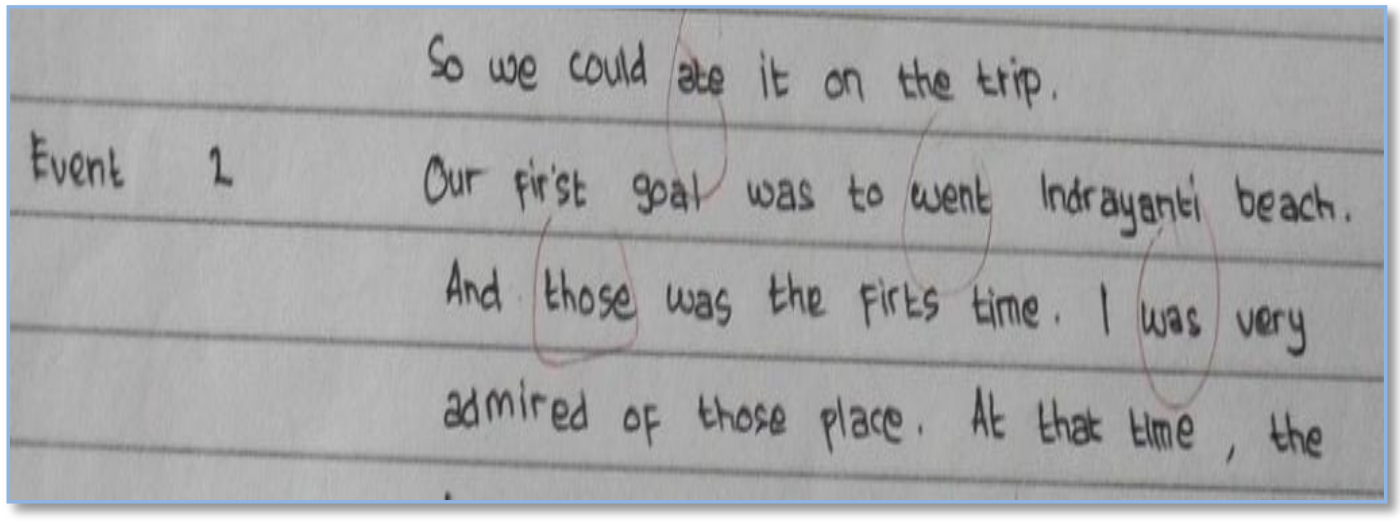

Figure 2 Indirect WCF

Although the teacher did not often employ metalinguistics, the teacher also thought that it could be helpful in assisting students in indicating the writing errors. This type was also used by providing the students the clues or codes in where the students did self-discovery. The students concentrated on specific and problematic language features.

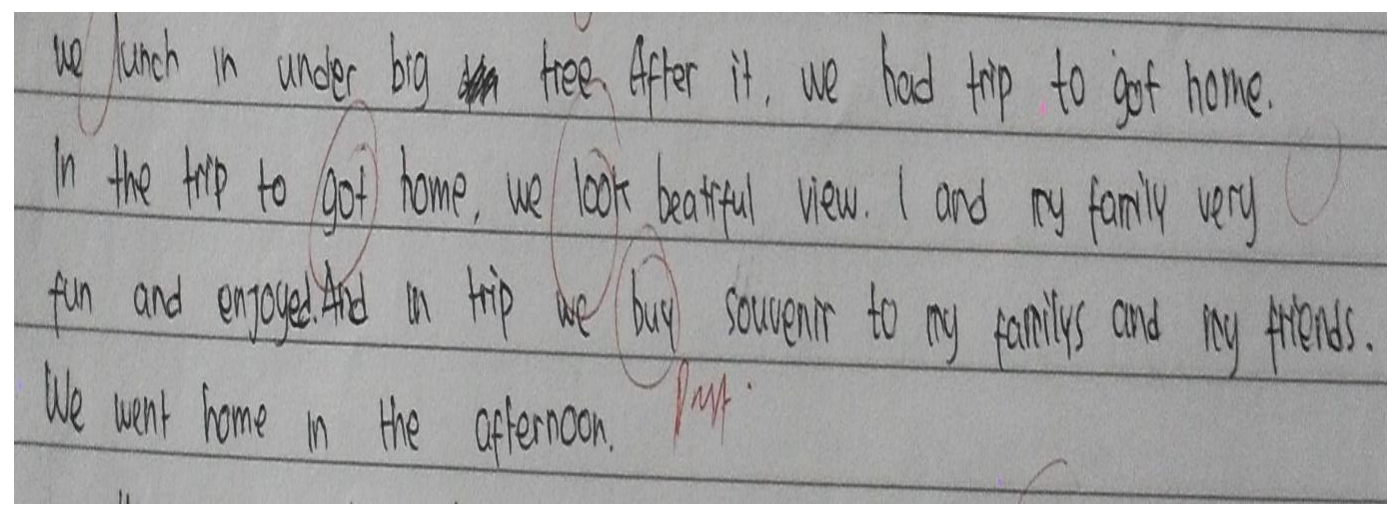

\section{Figure 3 Metalinguistics}

In respect to metalinguistics, it was found that the lecturer used two types of code of clue to guide the students to correct their own mistakes, "V" and "Past". The codes mean errors in verb tense. The teacher used code "V1" to inform the students that it had to be changed into present verb, code "V2" and "Past" means that the students had to correct into the past forms. The teacher hoped that they were able to utilize this knowledge in a form of self-discovery and self-correction. 
The next type of WCF used by the teacher was reformulation. Based on focus-group interviews, the students also liked this type since they received correction in the form of reformulated forms, so they knew the correct ones. The result of artifact analysis showed the teacher applied this technique by adding some letters and reforming the wrong words into the correct ones.

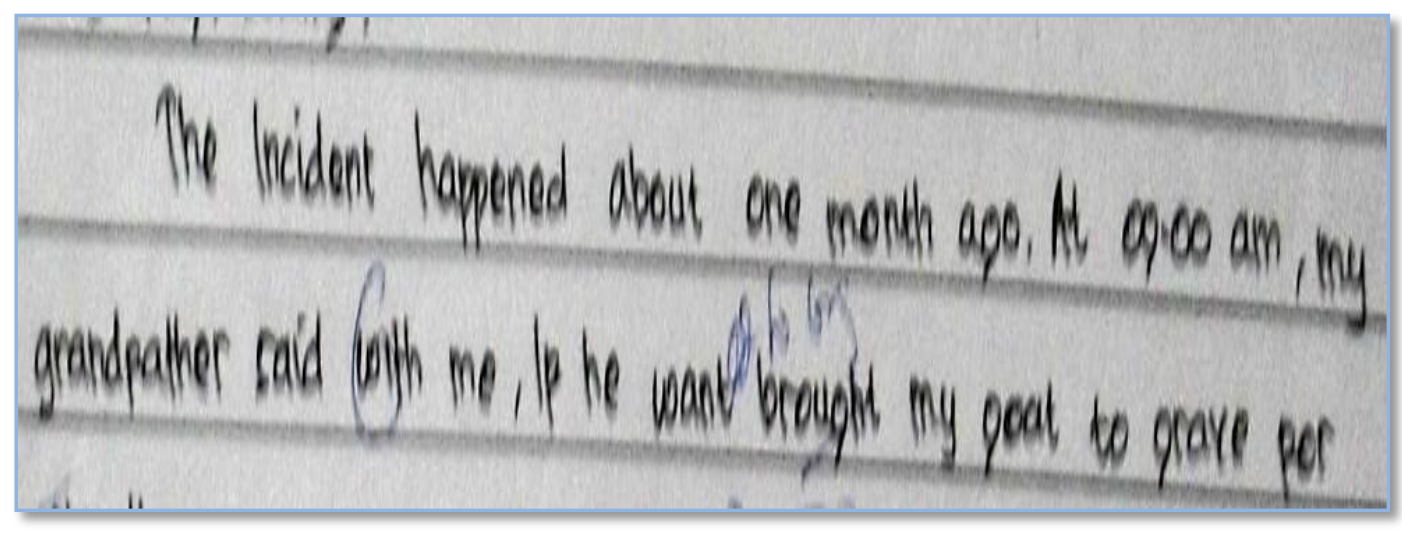

Figure 4 Reformulation

Concerning the knowledge about the importance of writing elements, Mrs. Sutiyem extensively corrected such elements as content, diction, grammatical structure, ideas, organization, spelling, and vocabulary but she emphasized more on grammar since the students' grammatical ability was still weak. She considered that this element was essential for her students to have a good piece of writing. Grammatical errors included the use of tense verbs (eg. At $01.00 \mathrm{pm}$ we go to Parangtritis should be At $01.00 \mathrm{pm}$ we go to Parangtritis), modal+verb construction (eg. We must passed many small stairs should be We must pass many small stairs.), personal pronoun usage (eg. Me and friend went to the beach should be My friend and I went to the beach), misuse of the genitive, " $s$ " (eg. Mother's came to Kemukus mountain should be Mother came to Kemukus mountain), 'be' usage (eg. We was walk about 2 hours. Instead of we walked about 2 hours), the article usage (eg. Culture Camp is a activity with... should be Culture Camp is an activity with ...), misuse of -ed and -ing forms (eg. The journey was interested. Instead of The journey was interesting), prepositional misuse (eg. In home, I worked my activity. Instead of At home, I worked my activity), and misuse of pluralization (eg. In the morning, we prepared many thing. Instead of In the morning, we prepared many things). 
Edukasi: Jurnal Pendidikan, Volume 19 Nomor 1 Tahun 2021

Written Corrective Feedback in Academic Writing Class.......

Dayat

Halaman 150-160

\section{Excerpt 3}

"The correction I had provided mostly on grammar since their grammar was still weak. Besides, other components also were corrected, for instance, content, diction, mechanics, vocabulary, and organization." (Teacher interview, January 8).

In respect to time allocation, Mrs. Sutiyem corrected the student writings after her students had completed their final drafts and she gave back the drafts for one week.

\section{Excerpt 3}

"I usually correct the students' drafts for one week." (Teacher interview, January 8).

Mrs. Sutiyem was aware that her WCF provision was much influenced by how the students learned in a particular socio-educational context. Mrs. Sutiyem about the adverse effects on WCF is suggested by the findings of a research which states that teachers avoid giving negative feedback for fear of embarrassing their students and creating an unfavorable learning environment (Hattie \& Yates, 2014). Therefore, Mrs. Sutiyem informed that she is trying to reduce the negative effects of WCF (usually language-error correction) by linking by giving good suggestions, thereby providing a concrete picture for future improvement.

\section{CONCLUSION}

The findings of this single case study have set out pedagogical implications for teachers in conceptualizing WCF and in learning and practicing it on their daily instruction based on their knowledge, experience, and reflection-onpractice. EFL/ESL teachers are encouraged to support their WCF practices with their pedagogical reasoning on the provision of their WCF. The findings of this research showed the teacher's practice on WCF could motivate and engage the students to revise so that their abilities in academic writing become improve. This research, therefore, contributes to the body of research on WCF in the sense that it provides evidence of how teachers' WCF for improving writing quality without making students unmotivated to learn. Thus, this case study suggests that EFL/ESL teachers should pay particular attention to students' ability and 
personality in providing $\mathrm{WCF}$ and give them an opportunity in terms of time allocation, to revise their writing drafts so that they learn from teachers' WCF as well as from their peers' feedback. Additionally, there must be some limitations to this research even though every effort was carried out to dispel the design and analytical flaws in this research. Therefore, consideration is required when further investigations into this topic are conducted. First, future research might consider involving more and higher proficiency teachers and comparing the WCF techniques used to be more effective and efficient in the same writing context. Finally, further research is expected to include more salient student responses and motivation changes over time, which could contribute insights into the role of responses and motivation in developing their writing quality.

\section{REFERENCES}

Banaruee, H., Khatin-Zadeh, O., \& Ruegg, R. (2018). Recasts vs. direct corrective feedback on writing performance of high school EFL learners. Cogent Education, 5(1), 1-23. http://dx.doi.org/10.1080/2331186X.2018.1455333.

Chen, S., Nassaji, H., \& Liu, Q. (2016). EFL learners' perceptions and preferences of written corrective feedback: A case study of university students from Mainland China. Asian-Pacific Journal of Second and Foreign Language Education, 1(5), 1-17. http://dx.doi.org/10.1186/s40862016-0010-y.

Ellis, R. (2010). A framework for investigating oral and written corrective feedback. Studies in Second Language Acquisition, 32(2), 335-349. http://dx.doi.org/10.1017/S0272263109990544.

Elola, I., Mikulski, A. M., \& Buckner, T. E. (2017). The impact of direct and indirect feedback on the development of Spanish aspect. Journal of Spanish Language Teaching, 4(1), 1-14. http://dx.doi.org/10.1080/23247797.2017. 1315267.

Ferris, D. R. (2015). Written corrective feedback in L2 Writing: Connors \& Lunsford (1988); Lunsford \& Lunsford (2008); Lalande (1982). Language Teaching, 48(4), 531-544. http://dx.doi.org/10.1017/S0261444815000257. 
Edukasi: Jurnal Pendidikan, Volume 19 Nomor 1 Tahun 2021

Written Corrective Feedback in Academic Writing Class.......

Dayat

Halaman 150-160

Ferris, D. R. (2011). Treatment of error in second language student writing (2nd ed.). Ann Arbor: The University of Michigan Press.

Fu, T., \& Nassaji, H. (2016). Corrective feedback, learner uptake, and feedback perception in a Chinese as a Foreign Language Classroom. Studies in Second Language Learning and Teaching, 6(1), 159-181. http://dx.doi.org/ 10.14746/ssllt.2016.6.1.8.

Hattie, J., \& Yates, G. (2014). Visible learning and the science of how we learn. New York: Routledge.

Jabulani, S. (2017). Efficacy of written corrective feedback on university students' writing. Journal of Social Sciences, 45(2), 84-95. http://dx.doi.org/10.1080/09718923.2015.11893490.

Kunzman, R. (2003). From teacher to student: The value of teacher education for experienced teacher. Journal of Teacher Education, 54(3), 241-253. http://dx.doi.org/10.1177/0022487103251568.

Lee, I. (2014). Revisiting teacher feedback in EFL writing from sociocultural perspectives. TESOL Quarterly, 48(1), 201-213. http://dx.doi.org/10.1002/ tesq.153.

Park, E. S., Song, S., \& Shin, Y. K. (2015). To what extent do learners benefit from indirect written corrective feedback? A study targeting learners of different proficiency and heritage language status. Language Teaching Research, 20(6), 678-699. http://dx.doi.org/10.1177/1362168815609617.

Putra, M. I. P., \& Sulaiman. (2016). Students' attitudes concerning lecturer's corrective feedback in teaching writing. Jurnal Pendidikan Bahasa, 5(2), 257-272. http://dx.doi.org/10.31571/bahasa.v5i2.329.

Sabarun, S. (2020). Direct teacher corrective feedback in EFL writing class at higher education: What Students Perceive. Vision: Journal for Language and Foreign Language Learning, 9(1), 18-33. http://dx.doi.org/ 10.21580/vjv9i14652.

Susanti, A. (2017). Teachers' corrective feedback on students' L2 writing: State of the art. Abjadia: International Journal of Education, 2(2), 81-94. https://doi.org/10.18860/abj.v2i2.5364. 
Thomas, K. E. (2018). Comparing explicit exemplar-based and rule-based corrective feedback: Introducing analogy-based corrective feedback. The Modern Language Journal, 102(2), 1-21. http://dx.doi.org/10.1111/ modl.12470.

Vyatkina, N. (2010). The effectiveness of written corrective feedback in teaching beginning German. Foreign Language Annals, 43(4), 671-689. http://dx.doi.org/10.1111/j.1944-9720.2010.01108.x.

Wei, W., \& Cao, Y. (2020). Written corrective feedback strategies employed by university English lecturers: A teacher cognition perspective. SAGE Open, 10(3), 1-12. https://doi.org/10.1177/2158244020934886.

Westmacott, A. (2017). Direct vs. indirect written corrective feedback: Student perceptions. Ikala, 22(1), 17-32. http://dx.doi.org/10.17533/udea.ikala. v22n01a02.

Yang, Y-F. (2017). New language knowledge construction through indirect feedback in web-based collaborative writing. Computer Assisted Language Learning, 31(4), 1-22. http://dx.doi.org/10.1080/09588221.2017.1414852.

Yu, S., \& Lee, I. (2016). Exploring Chinese students' strategy use in a cooperative peer feedback writing group. System, 58(June), 1-11. http://dx.doi.org/ 10.1016/j.system.2016.02.005.

Yunus, W. N. M. W. M. (2020). Written corrective feedback in English compositions: Teachers' practices and students' expectations. English Language Teaching Educational Journal, 3(2), 95-107. https://doi.org/ 10.12928/eltej.v3i2.2255.

Zabihi, S. (2013). The effect of recast on Iranian EFL learners' writing achievement. International Journal of Applied Linguistics and English Literature, 2(6), 28-35. http://dx.doi.org/10.7575/aiac.ijalel.v.2n.6p.28.

Zheng, Y., \& Yu, S. (2018). Student engagement with teacher written corrective feedback in EFL writing: A case study of Chinese lower-proficiency students. Assessing Writing, 37(July), 13-24. http://dx.doi.org/10.1016/ j.asw.2018.03.001. 